\title{
Desain dan Uji Coba Media Pembelajaran Berbasis Videoscribe Sebagai Sumber Belajar Pada Materi Bentuk Molekul Kelas X IPA SMA
}

\author{
Astari Shakina, Neti Afrianis \\ Program Studi Pendidikan Kimia, Universitas Islam Negeri Sultan Syarif Kasim Riau ${ }^{1)}$ \\ shakinaastr@gmail.com
}

\begin{abstract}
This research was instigated by the importance of technology-based learning facilities for students in learning Chemistry. This research aimed at knowing validity and practicality levels of the media designed. It was conducted to the tenth-grade students of MIA 2 of State Senior High School 1 Pekanbaru in the Academic Year of 2019/2020, and they were 12 students. It was Research and Development $(R \& D)$ with Borg and Gall modification model. The subjects of this research were who tested the validity (the experts of media and material) and practicality (teachers and students). Interview and questionnaire were used to collect the data. The final product was in the form of a valid learning media. Videoscribe-based learning media on Molecular Shapes lesson developed was tested valid by the experts of media and material with $91.87 \%$ mean percentage (very valid) and it was tested practical by 2 Chemistry subject teachers and 12 students with $91.02 \%$ mean percentage. Based on these findings, it could be concluded that Videoscribe-based learning media on Molecular Shapes lesson was valid and practical, sothe testcould be done at thefurther stage.
\end{abstract}

Keywords :Chemistry Learning Media, Videoscribe,Molecular Shapes

\section{PENDAHULUAN}

Era industri 4.0 adalah istilah yang digunakan untuk merujuk pada era dimana terjadi perpaduan teknologi yang mengakibatkan dimensi fisik, biologis, dan digital. Perkembangan teknologi digital di era industri 4.0 saat ini telah membawa perubahan dan mempengaruhi berbagai aspek kehidupan manusia, termasuk di bidang pendidikan. Hal ini disebabkan karena aspek efektivitas, efisiensi dan daya tarik yang ditawarkan oleh pembelajaran berbasis teknologi digital (Susilahudin \& Uswatun Hasanah, 2018).

Teknologi dalam pendidikan berusaha memecahkan atau memfasilitasi pemecahan masalah belajar pada manusia dalam segala situasi dan kondisi. Masih banyak peluang yang selama ini belum dimanfaatkan dan dikembangkan oleh para teknolog pendidikan (Abdulhak, 2018). Teknologi dalam pendidikan dapat digunakan untuk mengatasi masalahmasalah pendidikan. Salah satu masalah yang ditemukan adalah dalam pembelajaran kimia.

Kimia merupakan salah satu mata pelajaran IPA yang bersifat abstrak dan memiliki karakteristik yang berbeda serta membutuhkan pemahaman konsep (Kurniawati, 2018). Materi kimia terdiri atas perpaduan antara perhitungan dan konsep teoritis, sehingga kimia dianggap sulit dan membosankan untuk dipelajari (Pradilasari, 2019). Atom, molekul dan ion merupakan materi dasar kimia yang berukuran mikroskopis dan tidak dapat dilihat langsung oleh mata. Ilmu kimia saling berhubungan satu sama lain, sehingga untuk memahami materi kimia harus dipelajari secara berurutan. Sebelum masuk ke materi yang lebih kompleks, seorang individu harus memahami materi dasar terlebih dahulu agar tujuan pembelajaran dapat tercapai (Kurniawati, 2018). Untuk mencapai tujuan pembelajaran kimia diperlukan adanya media pembelajaran yang tepat agar pelajaran kimia dapat dipahami oleh peserta didik.

Media pembelajaran adalah suatu alat bantu berupa fisik maupun nonfisik yang sengaja digunakan sebagai perantara antara guru dan peserta didik dalam memahami materi pembelajaran agar lebih efektif dan efisien. Media pembelajaran dapat membantu guru dalam menyampaikan materi pembelajaran. Materi yang sulit akan lebih mudah dipahami oleh peserta didik dengan adanya media pembelajaran. Dengan kata lain, media 
pembelajaran merupakan alat bantu yang disesuaikan untuk meningkatkan kualitas pembelajaran (Musfiqon, 2012).

Media berbasis audio visual adalah salah satu contoh media pembelajaran. Media audio visual adalah berbagai macam media yang mengandung suara yang bisa didengar serta mengandung gambar yang bisa dilihat, contohnya yaitu slide suara, rekaman video dan lainnya. Media ini dianggap lebih menarik karena dinilai sangat optimal karena dapat meningkatkan motivasi dan minat belajar siswa serta dapat memperjelas materi yang disampaikan (Rosyida, 2017). Hasil penelitain Badian Susanti menyatakan bahwa penggunaan media audio visual dalam pembelajaran membuat pembelajaran lebih menarik, sehingga motivasi anak didik meningkat dan menghilangkan kejenuhan. Taraf berpikir anak dapat dilatih dari konkret ke abstrak, dari berpikir sederhana ke berpikir kompleks (Susanti, 2019). Videoscribe merupakan salah satu media pembelajaran yang berbasis audio visual.Software ini dikembangkan pada tahun 2012 oleh Sparkol salah satu perusahaan yang ada di Inggris. Videoscribe digunakan untuk penyajian informasi serta meningkatkan efektifitas pembelajaran (Yusup, 2016). Videoscribe adalah perangkat lunak yang digunakan untuk menghasilkan video animasi yang menarik dan mudah dengan mengabungkan teks, gambar, dan suara (Roudatus, 2020). Dengan adanya videoscribe maka diharapkan mampu mendukung dan mempermudah peserta didik untuk memahami dan menemukan konsepnya sendiri.

Bentuk molekul merupakan salah satu materi yang bersifat abstrak dan memerlukan daya pandang ruang yang baik sehingga untuk memahaminya memerlukan daya abstraksi yang tinggi. Berdasarkan hasil studi awal dengan guru kimia SMAN 1 Pekanbaru diperoleh informasi bahwa selama proses pembelajaran guru hanya menggunakan buku pelajaran kimia dengan metode diskusi. Media yang digunakan oleh guru masih terbatas, sehingga siswa kesulitan untuk menggambarkan bentuk molekul secara dua dimensi jika hanya melalui metode diskusi saja. Oleh karena itu, dibutuhkan suatu media pembelajaran yang bersifat interaktif dan menarik yang dapat membantu pemahaman peserta didik terhadap materi bentuk molekul. .

Berdasarkan latar belakang tersebut peneliti mengembangkan suatu media pembelajaran berupa media audio visual berbasis videoscribe yang bertujuan untuk menganalisis tingkat validitas dan praktikalitas "Media Pembelajaran Berbasis Videoscribe sebagai Sumber Belajar Pada Materi Bentuk Molekul Kelas X IPA SMA" sebagai salah satu media pembelajaran interaktif dan menarik.

\section{METODE PENELITIAN}

Penelitian ini menggunakan metode penelitian dan pengembangan (Research and Development) dengan model yang berasal dari hasil pemikiran, masih bersifat konseptual dan pelaksanaannya terorganisasi mulai dari perencanaan, pelaksanaan sampai pada evaluasi hasilnya (Endang, 2014).

Model pengembangan yang digunakan pada penelitian ini adalah model Borg \& Gall yang terdiri dari sepuluh tahapan. Borg \& Gall menyatakan bahwa dimungkinkan bagi peneliti untuk membatasi penelitian dalam skala kecil, termasuk membatasi langkah penelitian (Emzir, 2008). Dalam penelitian ini hanya dilakukan sampai tahap kelima, yaitu: (1) penelitian dan pengumpulan informasi, (2) perencanaan, (3) pengembangan produk bentuk awal, (4) uji coba lapangan awal, (5) revisi produk.

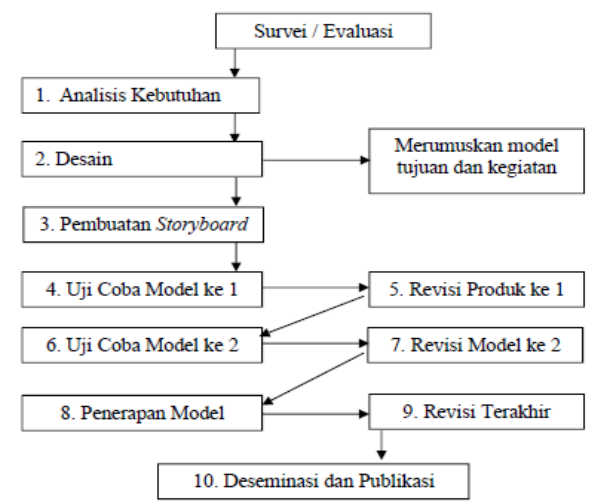

Gambar 1. Prosedur Penelitian

Pada penelitian ini dihasilkan produk berupa media pembelajaran berbasis videoscribe sebagai sumber belajar pada materi bentuk molekul. Pembuatan media ini dimulai dengan melakukan install aplikasi sparkol videoscribe versi 3.2.0 pada komputer. Setelah aplikasi terpasang pada komputer, dimulai dengan membuka halaman kerja baru dan memasukkan objek yang sesuai dengan materi bentuk molekul. Untuk pembuatan struktur lewis pada materi, terlebih dahulu struktur lewis tersebut ditulis pada kertas putih kemudian difoto dan background foto dihilangkan menggunakan aplikasi background eraser. Setelah video selesai 
dibuat, ditambahkan narasi dengan menggunakan perekam suara dan diedit menggunakan aplikasi windows movie maker.

Objek yang diteliti pada penelitian ini adalah media pembelajaran berbasis videoscribe sebagai sumber belajar pada materi bentuk molekul. Subjek dalam penelitian ini adalah pihak yang melakukan uji validitas (ahli media dan ahli materi), uji praktikalitas (2 orang guru) dan uji respon oleh 12 orang peserta didik. Instrumen dalam penelitian ini berupa angket, yaitu angket uji validitas, angket uji praktikalitas dan angket uji respon peserta didik yang bertujuan untuk memperoleh informasi yang relevan. Penilaian instrumen disusun berdasarkan rating scale. Adapun skala angket dapat dilihat pada Tabel 1.

Tabel 1. Skala Angket

\begin{tabular}{cc}
\hline $\begin{array}{c}\text { Jawaban Item } \\
\text { Instrumen }\end{array}$ & Skor \\
\hline Sangat baik & 4 \\
\hline Baik & 3 \\
\hline Tidak Baik & 2 \\
\hline Sangat Tidak Baik & 1 \\
\hline
\end{tabular}

Teknik analisis data yang digunakan adalah analisis deskriptif kualitatif yang digunakan untuk mengolah data hasil review dari ahli media, ahli materi pembelajaran, guru dan peserta didik berupa saran dan masukan mengenai perbaikan pada media. Sedangkan analisis deskriptif kuantitatif digunakan untuk menganalisis hasil yang diperoleh dari angket uji validitas dan uji praktikalitas para ahli berupa angka (Riduwan, 2014).

Data yang diperoleh berupa data kualitatif yang dikuantitatifkan dengan pengukuran skala. Untuk menghitung persentase kevalidan dan kepraktisan produk digunakan rumus menghitung persentase (Riduwan, 2014).

$$
\text { Persentase }=\frac{\text { skoryangdiperoleh }}{\text { skormaksimal }} \times 100 \%
$$

Hasil persentase dari uji kevalidan dan kepraktisan dapat ditafsirkan dalam bentuk kualitatif (Riduwan, 2014). Adapun kriteria uji validitas dan uji praktikalitas dapat dilihat pada tabel 2.

Tabel 2. Kriteria Uji Validitas dan Uji Praktikalitas

Persentase Pencapaian Interpretasi

\begin{tabular}{cc}
\hline $85,01 \%-100,00 \%$ & $\begin{array}{c}\text { Sangat } \\
\text { valid/Praktis }\end{array}$ \\
\hline $70,01 \%-85,00 \%$ & Valid/Praktis \\
\hline $50,01 \%-70,00 \%$ & $\begin{array}{c}\text { Kurang } \\
\text { Valid/Praktis }\end{array}$ \\
\hline $01,00 \%-50,0 \%$ & $\begin{array}{c}\text { Tidak } \\
\text { Valid/Praktis }\end{array}$ \\
\hline
\end{tabular}

Produk dikatakan valid/praktis jika persentase minimal berada pada kriteria valid/praktis yaitu $70,01 \%-85,00 \%$. Kemudian data tersebut diinterpretasikan dengan teknik deskriptif, sehingga dapat dilihat sejauh mana tingkat validitas/praktikalitas media pembelajaran berbasis videoscribe.

\section{HASIL DAN PEMBAHASAN}

\section{a. Tahap Pengumpulan Data}

Sebelum melaksanakan penelitian, terlebih dahulu peneliti melakukan pengumpulan data yang dilakukan dengan survei lapangan dan studi pustaka. Survei lapangan yang dilakukan peneliti yaitu dengan menganalisis KI dan KD. Selanjutnya peneliti melakukan wawancara dengan guru SMAN 1 Pekanbaru didapat bahwa selama proses pembelajaran guru hanya menggunakan buku pelajaran kimia dengan metode diskusi. Media yang digunakan oleh guru masih terbatas, sehingga siswa kesulitan untuk menggambarkan bentuk molekul secara dua dimensi jika hanya melalui metode diskusi saja. Oleh sebab itu dibutuhkan suatu sumber belajar yang menarik dan diharapkan mampu mendukung dan mempermudah peserta didik untuk memahami materi pembelajaran. Videoscribe dipilih karena penggunaannya sangat mudah dan tidak memerlukan keahlian khusus. .

\section{b. Tahap Perencanaan}

Tahap selanjutnya adalah tahap perencanaan yaitu menyesuaikan kompetensi inti dan kompetensi dasar serta silabus berdasarkan kurikulum 2013, merancang desain awal media serta menyusun instrumen penelitian.

\section{c. Tahap Pengembangan Produk}

Produk yang dihasilkan dari aplikasi sparkol videoscribe berupa file video. Media pembelajaran berbasis videoscribe pada materi bentuk molekul yang dirancang terdiri dari tiga bagian, yaitu bagian pendahuluan, bagian isi dan bagian penutup. 

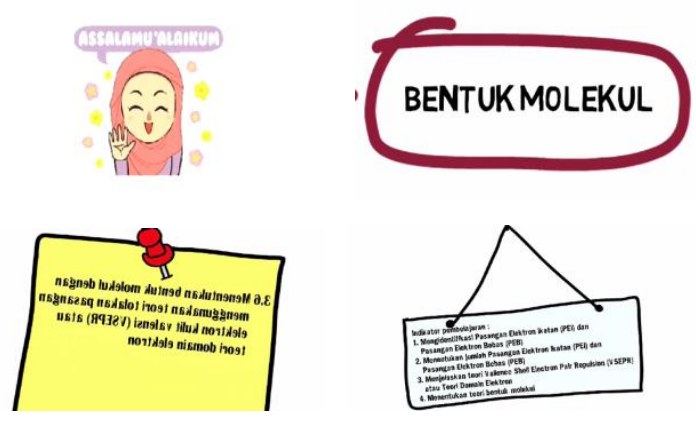

Gambar 2. Tampilan pendahuluan media pembelajaran berbasis Videoscribe
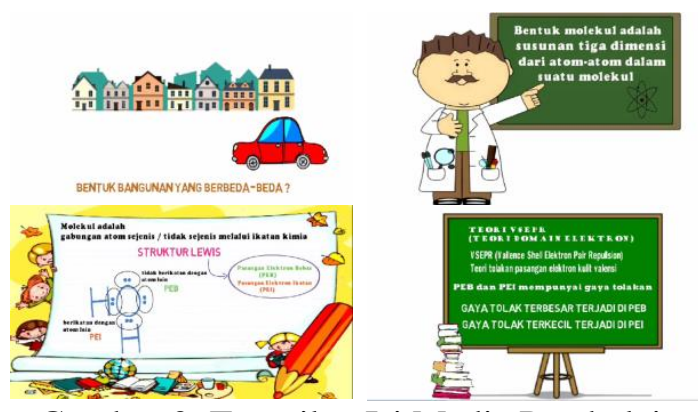

Gambar 3. Tampilan Isi Media Pembelajaran berbasis Videoscribe
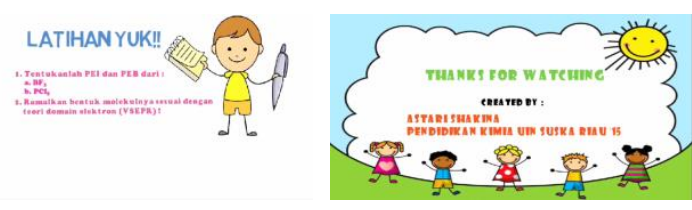

Gambar 4. Tampilan Penutup Media Pembelajaran berbasis Videoscribe

Setelah media dikembangkan kemudian divalidasi oleh 2 orang dosen sebagai ahli media dan ahli materi. Adapun hasil uji validasi dari ahli media dan ahli materi dapat dilihat pada Tabel 3 dan Tabel 4.

Tabel 3. Hasil Validasi oleh Ahli Media

\begin{tabular}{lccc}
\hline $\begin{array}{c}\text { Indikator/ } \\
\text { Aspek }\end{array}$ & Skor & $\%$ & Kriteria \\
\hline Aspek & 15 & $93.75 \%$ & $\begin{array}{c}\text { Sangat } \\
\text { Valid }\end{array}$ \\
$\begin{array}{l}\text { Desain } \\
\text { Pembelajaran }\end{array}$ & & & \\
\hline Aspek & 24 & $85.71 \%$ & Sangat \\
Tampilan & & & \\
Media & & & \\
Audio Visual & & & \\
\hline Aspek & 10 & $83.33 \%$ & Valid \\
Pemanfaatan & & & \\
Software & & & \\
\hline
\end{tabular}

\begin{tabular}{lcc}
\hline Rata-rata & $\mathbf{8 7 . 5 \%}$ & $\begin{array}{c}\text { Sangat } \\
\text { Valid }\end{array}$ \\
\hline
\end{tabular}

Dari hasil validasi media oleh ahli media, media pembelajaran berbasis videoscribe dikategorikansangat valid dengan persentase kevalidan $87.5 \%$, yang artinya media layak untuk diujicobakan di sekolah.

Tabel 4. Hasil Validasi oleh Ahli Materi

\begin{tabular}{|c|c|c|c|}
\hline $\begin{array}{c}\text { Indikator/ } \\
\text { Aspek }\end{array}$ & Skor & $\%$ & Kriteria \\
\hline $\begin{array}{l}\text { Aspek } \\
\text { Kebenaran, } \\
\text { Keluasan, dan } \\
\text { Kedalaman } \\
\text { Materi }\end{array}$ & 28 & $100 \%$ & $\begin{array}{l}\text { Sangat } \\
\text { Valid }\end{array}$ \\
\hline $\begin{array}{l}\text { Aspek } \\
\text { Kebahasaan }\end{array}$ & 7 & $87.5 \%$ & $\begin{array}{c}\text { Sangat } \\
\text { Valid } \\
\end{array}$ \\
\hline $\begin{array}{l}\text { Aspek } \\
\text { Keterlaksanaan }\end{array}$ & 8 & $100 \%$ & $\begin{array}{c}\text { Sangat } \\
\text { Valid }\end{array}$ \\
\hline $\begin{array}{l}\text { Aspek Tampilan } \\
\text { Media Audio } \\
\text { Visual }\end{array}$ & 11 & $91.67 \%$ & $\begin{array}{l}\text { Sangat } \\
\text { Valid }\end{array}$ \\
\hline Aspek Suara & 11 & $91.67 \%$ & $\begin{array}{c}\text { Sangat } \\
\text { Valid } \\
\end{array}$ \\
\hline $\begin{array}{l}\text { Aspek } \\
\text { Pemanfaatan } \\
\text { Software }\end{array}$ & 12 & $100 \%$ & $\begin{array}{l}\text { Sangat } \\
\text { Valid }\end{array}$ \\
\hline Rata-rata & & $96.25 \%$ & $\begin{array}{c}\text { Sangat } \\
\text { Valid }\end{array}$ \\
\hline
\end{tabular}

Dari hasil validasi materi oleh ahli materi, media pembelajaran berbasis videoscribe dikategorikan sangat valid dengan persentase kevalidan $96.25 \%$, yang artinya materi dalam media sudah sesuai KI \& KD dan media layak untuk diujicobakan di sekolah.

\section{d. Tahap Uji Coba Lapangan Awal}

Media pembelajaran berbasis videoscribe yang sudah valid selanjutnya diujicobakan ke sekolah. Uji coba dilaksanakan di SMA Negeri 1 Pekanbaru yaitu kepada 2 orang guru kimia dan 12 orang peserta didik kelas X MIA 2. Hasil uji coba ini dipakai untuk mengetahui praktikalitas produk dan respon peserta didik terhadap produk yang didesain. Adapun hasil uji praktikalitas dari 2 orang guru Kimia di SMA Negeri 1 Pekanbaru dan hasil uji respon dari 12 orang peserta didik dapat dilihat pada Tabel 5 dan Tabel 6. 
Tabel 5. Hasil Uji Praktikalitas dari 2 Orang Guru Kimia

\begin{tabular}{lccc}
\hline \multicolumn{1}{c}{$\begin{array}{c}\text { Indikator/ } \\
\text { Aspek }\end{array}$} & Skor & $\%$ & Kriteria \\
\hline $\begin{array}{l}\text { Aspek } \\
\text { Kebenaran, } \\
\text { Keluasan, } \\
\text { dan Kedalaman }\end{array}$ & 46 & $95.83 \%$ & $\begin{array}{l}\text { Sangat } \\
\text { Materi }\end{array}$ \\
\hline Aspek & & & \\
Kebahasaan & 16 & $100 \%$ & $\begin{array}{l}\text { Sangat } \\
\text { Praktis }\end{array}$ \\
\hline Aspek & 15 & $93.75 \%$ & Sangat \\
Keterlaksanaan & & & Praktis \\
\hline Aspek & 37 & $92.5 \%$ & $\begin{array}{l}\text { Sangat } \\
\text { Tampilan }\end{array}$ \\
Media & & & Praktis \\
\hline $\begin{array}{l}\text { Aspek } \\
\text { Suara }\end{array}$ & 15 & $93.75 \%$ & $\begin{array}{l}\text { Sangat } \\
\text { Praktis }\end{array}$ \\
\hline Aspek & 15 & $93.75 \%$ & Sangat \\
Pemanfaatan & & & Praktis \\
Software & & & \\
\hline \multicolumn{1}{c}{ Rata-rata } & & $\mathbf{9 4 . 7 3 \%}$ & $\begin{array}{l}\text { Sangat } \\
\text { Praktis }\end{array}$ \\
\hline
\end{tabular}

Dari hasil uji praktikalitas oleh 2 orang guru kimia, media pembelajaran berbasis videoscribe dikategorikan sangat praktis dengan persentase kepraktisan $94.73 \%$, yang artinya media layak digunakan oleh guru di sekolah. Berikut ini hasil persentase dari setiap indikator penilaian sebagaimana dianalisis secara kuantitatif.

\section{1) Indikator Kebenaran, Keluasan dan Kedalaman Materi}

Kebenaran, keluasan dan kedalaman materi dari media ini termasuk kategori sangat praktis dengan persentase $95.83 \%$ dengan demikian materi yang disajikan pada media pembelajaran berbasis videoscribe sudah sesuai dengan $\mathrm{KI} / \mathrm{KD}$, tujuan pembelajaran dan indikator pembelajaran. Hal ini sesuai dengan pendapat Aprida Pane, bahwa materi yang tepat dapat membantu peserta didik untuk mencapai $\mathrm{KI} / \mathrm{KD}$ dan tujuan pembelajaran.

\section{2) IndikatorKebahasaan}

Bahasa dalam media ini termasuk kategori sangat praktis dengan persentase $100 \%$ dengan demikian bahasa yang digunakan dalam media pembelajaran berbasis videoscribe yang dihasilkan sudah mengacu pada pedoman ejaan yang disempurnakan sehingga mudah dipahami peserta didik dalam proses pembelajaran. Hal ini sesuai dengan pendapat Wicaksono (2016), bahwa bahasa merupakan komunikasi yang penting dalam pembelajaran, bahasa dapat menjadi penentu keberhasilan dalam kegiatan pembelajaran jika bahasa yang digunakan sesuai dengan kaidah dan mudah dipahami.

\section{3) Indikator Keterlaksanaan}

Keterlaksanaan dari media ini termasuk kategori sangat praktis dengan persentase 93.75\% dengan demikian media pembelajaran berbasis videoscribe dapat membantu peserta didik dalam memahami materi bentuk molekul. Hal ini sesuai dengan pendapat Badian Susanti, bahwa penggunaan media pembelajaran videoscribe dalam pembelajaran dapat memberikan pemahaman kepada peserta didik, memberikan stimulus dan memusatkan perhatian peserta didik (Susanti, 2019).

\section{4) Indikator Tampilan Media}

Tampilan media dari media ini termasuk kategori sangat praktis dengan persentase $92.5 \%$ dengan demikian desain media pembelajaran berbasis videoscribe dapat menarik perhatian siswa dalam proses pembelajaran, penyajian media urut dan runtut sehingga memudahkan siswa dalam memahami materi bentuk molekul dan gambar maupun animasi sudah sesuai dengan materi bentuk molekul. Hal ini sesuai dengan pendapat Badian Susanti, bahwa tampilan media pembelajaran videoscribe yang menarik dapat meningkatkan motivasi peserta didik, menghilangkan kejenuhan dalam belajar dan meningkatkan pemahaman peserta didik (Susanti, 2019).

\section{5) Indikator Suara}

Suara dari media ini termasuk kategori sangat praktis dengan persentase $93.75 \%$ dengan demikian suara/audio dalam penyajian media pembelajaran berbasis videoscribe oleh narator terdengar jelas dan musik pengiring dalam video memberikan kesan semangat sehingga peserta didik lebih semangat belajar dan memahami materi yang disajikan. Hal ini sesuai dengan pendapat Lely Halimah, bahwa suara atau musik dapat membangkitkan motivasi peserta didik dan memperbaiki konsentrasi sehingga peserta didik dapat memahami materi yang disajikan (Halimah, 2016).

\section{6) Indikator Pemanfaatan Software}

Pemanfaatan software pada media ini termasuk kategori sangat praktis dengan persentase $93.75 \%$ karena media pembelajaran berbasis videoscribe dapat digunakan sebagai alternatif bahan ajar inovatif dan dapat digunakan secara mandiri dan berulang-ulang kapanpun dan 
dimanapun oleh peserta didik. Hal ini sesuai dengan pendapat Yasinta, bahwa media pembelajaran berbasis videoscribe dapat digunakan sebagai bahan ajar yang menarik dan inovatif (Yasinta, 2016).

Tabel 6. Hasil Uji Respon dari 12 Orang Peserta Didik

\begin{tabular}{|c|c|c|c|}
\hline $\begin{array}{c}\text { Indikator/ } \\
\text { Aspek }\end{array}$ & Skor & $\%$ & Kriteria \\
\hline $\begin{array}{l}\text { Aspek } \\
\text { Materi }\end{array}$ & 205 & $85.41 \%$ & $\begin{array}{l}\text { Sangat } \\
\text { Praktis }\end{array}$ \\
\hline $\begin{array}{l}\text { Aspek } \\
\text { Kebahasaan }\end{array}$ & 45 & $93.75 \%$ & $\begin{array}{l}\text { Sangat } \\
\text { Praktis } \\
\end{array}$ \\
\hline $\begin{array}{l}\text { Aspek } \\
\text { Ketertarikan }\end{array}$ & 253 & $87.84 \%$ & $\begin{array}{l}\text { Sangat } \\
\text { Praktis }\end{array}$ \\
\hline Rata-rata & & $87.32 \%$ & $\begin{array}{l}\text { Sangat } \\
\text { Praktis }\end{array}$ \\
\hline
\end{tabular}

Dari hasil uji respon 12 orang peserta didik, media pembelajaran berbasis videoscribe dikategorikan sangat praktis dengan persentase kepraktisan $87.32 \%$, yang artinya media tersebut layak digunakan oleh peserta didik dalam pembelajaran kimia. Berikut ini hasil persentase dari setiap indikator penilaian sebagaimana dianalisis secara kuantitatif.

\section{1) Indikator Materi}

Indikator materi dari media ini termasuk dalam kategori sangat praktis dengan persentase $85.41 \%$ dengan demikian materi yang disampaikan dalam media pembelajaran berbasis videoscribe mudah dipahami oleh peserta didik.Hal ini sesuai dengan pendapat Yusup, bahwa media pembelajaran videoscribe dapat membantu peserta didik untuk memahami materi (Yusup, 2016).

\section{2) Indikator Kebahasaan}

Indikator kebahasaan dari media ini termasuk dalam kategori sangat praktis dengan persentase $93.75 \%$ dengan demikian media pembelajaran berbasis videoscribe sudah menggunakan bahasa yang mudah dipahami, karena media ini disusun menggunakan bahasa sederhana, jelas dan terstruktur.Hal ini sesuai dengan pendapat Luhur Wicaksono, bahasa dapat menjadi penentu keberhasilan dalam kegiatan pembelajaran jika bahasa yang digunakan sesuai dengan kaidah dan mudah dipahami (Wicaksono, 2016).

\section{3) Indikator Ketertarikan}

Indikator ketertarikan dari media ini termasuk dalam kategori sangat praktis dengan persentase $87.84 \%$ dengan demikian media pembelajaran berbasis videoscribe yang dihasilkan menarik perhatian peserta didik dan pembelajaran lebih mudah dipahami. Hal ini sesuai dengan pendapat Fitri Nurjanah, bahwa penggunaan videoscribe sebagai media pembelajaran dapat menarik perhatian peserta didik karena kegiatan pembelajaran menjadi lebih menarik, mampu memperjelas konsep yang abstrak dan tujuan pembelajaran lebih cepat tercapai (Nurjanah, 2017).

\section{e. Tahap Revisi}

Revisi tahap akhir dilakukan untuk menghasilkan produk final yaitu media pembelajaran berbasis videoscribe pada materi bentuk molekul. Adapun beberapa saran dan masukan dari 2 orang guru kimia SMA Negeri 1 Pekanbaru dapat dilihat pada Tabel 7 berikut.

Tabel 7. Saran dan Masukan dari Guru Kimia

\begin{tabular}{ccl}
\hline No. & Inisial Guru & Saran dan Masukan \\
\hline 1. & DE & $\begin{array}{l}\text { Videoscribe sudah } \\
\text { dapat digunakan }\end{array}$ \\
& & untuk media \\
& pembelajaran bentuk \\
& & molekul \\
\hline 2. & DS & Media pembelajaran \\
& & cukup menarik buat \\
& peserta didik dan \\
& untuk \\
& kesempurnaannya \\
& diperlukan perbaikan \\
\hline
\end{tabular}

Penggunaan media dalam suatu pelajaran sangat penting, karena dengan adanya sebuah media maka materi yang disampaikan akan lebih jelas dan mudah dipahami serta dapat memotivasi peserta didik untuk lebih semangat dalam belajar. Pembelajaran dengan menggunakan suatu media akan berlangsung efektif sehingga tujuan pembelajaran akan tercapai.

Berdasarkan analisis terhadap keseluruhan hasil penelitian, mulai dari desain pembuatan hingga implementasinya menunjukkan bahwa media pembelajaran berbasis videoscribe memiliki beberapa kelebihan sebagai berikut:

1. Media sangat mudah untuk dibuat oleh guru.

2. Media mudah digunakan untuk pembelajaran di kelas maupun mandiri.

3. Media dapat dioperasikan menggunakan gadget dan sejenisnya.

4. Dilengkapi gambar, audio, yang berisikan penjelasan mengenai materi bentuk molekul. 
Selain memiliki kelebihan, media pembelajaran berbasis videoscribe juga memiliki kelemahan, yaitu:

1. Materi yang dikembangkan pada penelitian ini hanya materi bentuk molekul.

2. Dalam proses export video membutuhkan waktu yang cukup lama.

3. Harus berbayar jika ingin akses lebih lengkap.

Oleh karena itu dibutuhkan penelitian lebih lanjut untuk mengetahui efektifitas penggunaan media pembelajaran berbasis videoscribe sebagai sulber belajar inovatif di SMA.

\section{KESIMPULAN}

Berdasarkan penelitian dan analisis data yang telah dilakukan, maka dapat diperoleh kesimpulan sebagai berikut:

1) Tingkat Validitas media pembelajaran berbasis videoscribe pada materi bentuk molekul berdasarkan hasil analisis data validasi oleh ahli media dengan persentase kevalidan sebesar $87.5 \%$ yang dikategorikan sangat valid, sedangkan dari hasil validasi oleh ahli materi dengan persentase kevalidan sebesar $96.25 \%$ yang dikategorikan sangat valid.

2) Tingkat praktikalitas media pembelajaran berbasis videoscribe pada materi bentuk molekul berdasarkan hasil analisis data uji praktikalitas pada 2 orang guru kimia dengan persentase kepraktisan sebesar $94.73 \%$ dengan kriteria sangat praktis.

3) Uji respon peserta didik terhadap media pembelajaran berbasis videoscribe berdasarkan hasil analisis data yang telah dikumpulkan dari uji respon terhadap 12 orang peserta didik dengan persentase kepraktisan $87.32 \%$ dengan kriteria sangat praktis.

\section{DAFTAR PUSTAKA}

Emzir. (2014). Metodologi Penelitian Pendidikan Kuantitatif dan Kualitatif. Jakarta: RajawaliPress.

Halimah, Lely. (2016). Musik dalam Pembelajaran. Jurnal Pendidikan Dasar. Vol. 02, No. 02.

Ishak, A. (2013). Teknologi Pendidikan. Bandung: PT. Remaja Rosda Karya
Kurniawati, Y. (2018). Teknik Penyusunan Instrumen Penelitian Pendidikan Kimia. Pekanbaru: Kreasi Edukasi

Mulyatiningsih, E. (2014). Metode Penelitian Terapan Bidang Pendidikan. Bandung: Alfabeta

Musfiqon. (2012). Pengembangan Media dan Sumber Pembelajaran. Jakarta: PT. Prestasi Pustakarya

Nurjanah, Fitri. (2017). Pengembangan Media Animasi Menggunakan Software Videoscribe pada materi Minyak Bumi Kelas X MIA di Man Darussalam. JIMPK, Vol. 2, No. 4. Universitas Syaiah Kuala.

Pane, Aprida. (2017). Belajar dan Pembelajaran. Jurnal Kajian Ilmu-Ilmu KeIslaman. Vol. 03, No. 2.

Putrawangsa., Susilahudin., \& Uswatun, H. (2018). Integrasi Teknologi Digital dalam Pembelajaran di Era Industri 4.0. Jurnal Pemikiran dan Penelitian Pendidikan, 16(1), 42-54.

Pradilasari, L., Gani, A., \& Khaldun, I. (2019). Pengembangan Media Pembelajaran Berbasis Audio Visual pada Materi Koloid Untuk Meningkatkn Motivasi dan Hasil Belajar Siswa SMA. Indonesian Journal of Science Education, 7(1), 9-15.

Riduwan, (2014). Dasar-Dasar Statistika. Bandung: Alfabeta.

Rosyida, S., Munzil., \& Joharmawan, R. (2017). Pengaruh Penggunaan Media Audio Visual dalam Pembelajaran Problem Posting Terhadap Motivasi dan Hasil Belajar Larutan Penyangga. Jurnal Pembelajaran Kimia, 2(1), 41-52.

Sarifah, S., \& Ulfa, S.M. (2020). The Effectiveness of Videoscribe as Innovative Media to Increase Students Reading Comprehesion. English Teaching Journal, 8(1), 19-24.

Susanti, Badian. (2019). Penggunaan Media Pembelajaran Videoscribe untuk Meningkatkan Minat Belajar Siswa Kelas V Madrasah Ibtidaiyah At-Taqwa Pinang Kota Tangerang Tahun 2018. Jurnal 
Kajian Penelitian dan Pendidikan dan Pembelajaran. Vol. 03, No. 02.

Wicaksono, Luhur. (2016). Bahasa dalam Komunikasi Pembelajaran. Journal of Presspectif Learning. Vol. 01, No.02.

Yasinta. (2016). Pengembangan Media Pembelajaran Mekanika Teknik Berbasis Videoscribe dan Aurora 3D Presentation pada Materi Konstruksi Pelengkung Tiga Sendi. Jurnal UNY: Yogyakarta.

Yusup, M., Aini, Q., \& Pertiwi, K.D. (2016). Media Audio Visual Menggunakan Videoscribe Sebagai Penyajian Informasi Pembelajaran pada Kelas Sistem Operasi. Technomedia Journal (TMJ), 1(1), 126138. 